\title{
繊 維助劑に就いて
}

\section{宮 岡 宇 一 郎}

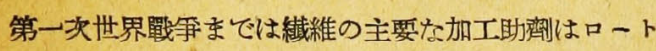

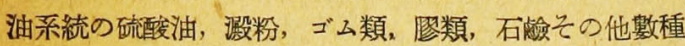
に過ぎず，加工は專ら機绒的であつた。例へは艶出，採 布、シユライナー，エンボシング，シルケット等であつ て化學的な加工はあまり行はれなかつた。最近になつて

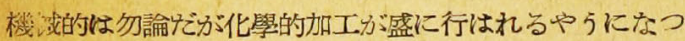
たそれで今や化學的加工㑚，加工法の知識なしでは技

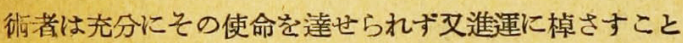
が汕來ない狀態となつた。然らば何故に化學的加工が今 日のように盛大になつたか。それには次のやらな諸點を 擧げること分出來る。

1. 有機化學䛈に染料工業の發達乃゙その副産物たる製 品に䋳維工業への道を開き，その初期の製品が新なる製 品の研究, 發達に導いたとと。

2. 近代流行の複雜性とはげしい變化。

3. 多數の新瀻維, 多種の編織物の出現によつて新な る染法，加工法を要求したこと等である。そして今や化

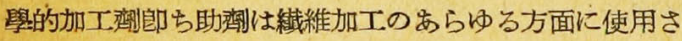
れてるる。すなはち硬水障害防止，洗淢及び滑淨、潤滑， 潤滑浸透，糊料，糊找，縮䋐シシルケット，漂白均染，

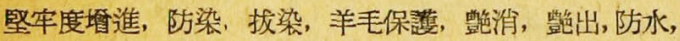

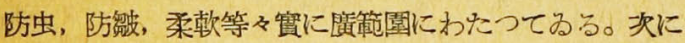

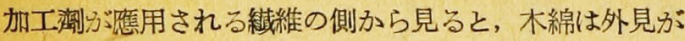
最も平凡大そから一番良く化學的加工が行はれ人絹はこれ К次ぐ。麻，羊毛，絹は夫々自體が特性家持つから例外 はあるが化學的加工は餘り必要でなく穼ろ他種瀻維をこ れに擬似せしめることが行はれる。まを織物の種類から 見ると平織には最も多く加工を要し複雜なるの程加工を

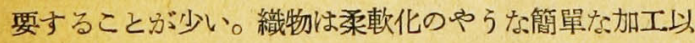
外特別な加工を要しないことが多い。

次に最近まで出現した重要な加工劑をその構造から分 類すると

1. 長鎖狀炭化水素化合物

a. 陰イオン性活性化合物；占. 陽イオン性活性化合 物，就中第 4 次アンモニウム化合物； c. 非イオン 性化合物

2. 合成樹脂

\section{3. 繊維素誘導體}

これ等のるのはすべてコロイド性のものでその多くは 水中で電荷を有し普通のイオンの性質を示すから膠狀電 解質と呼ばれる。

次に以上列舉した各尰の加工劑について證明しょう。

(1) 長鎖狀岸化水素化合物

各種の助劑は普通の電解質のやうに水中て電䡈しイオ ンを生ずる，ななは号 $\mathrm{R}-\mathrm{XY} \leadsto[\mathrm{R}-\mathrm{X}]-+\mathrm{Y}$

こつに $\mathrm{R}$ は嫌水性の主に脂肪屬炭化水素の残基， $\mathrm{X}$ 文 び Y はイオン化性の群である。上式のやうに助劑定水 中に入れると陰イオンと陽イオンが出來る。それで脂肪 残基岂示すイオンが負電荷它持てば（例へば $[\mathrm{R}-\mathrm{X}]$ 一) 之を陰イオン活性化合物と云ひ区對に正電荷を持てば (例へば $\left.[\mathrm{R}-\mathrm{X}]^{+}\right)$陽イオン活性化合物と云ふ。

\section{A. 陰イオン活性化合物}

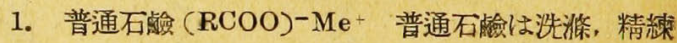

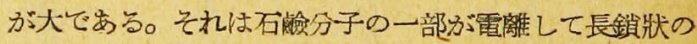
陰イオンと小さな陽イオンを作る。この陰イオンは非解

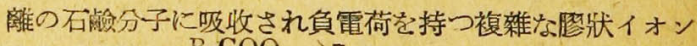
を作る。郎ち $\left.\begin{array}{l}\text { R-COO } \\ \text { R COONa }\end{array}\right)^{-} \mathrm{Na}^{+}$からる複䆶な陰イオン

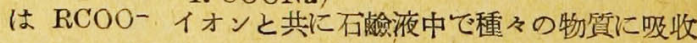
され負電荷の薄膜を作り液中にその物質と共に分散す

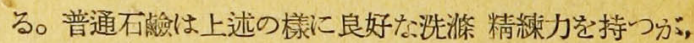
その中に $\mathrm{COOH}$ 群苍有するために石灰 マグネシウム と結合し沈澱すること，酸によつて分解することの大き な缺點をもつ。この缺點を除くものとして生れたのが次 の諸種の硫酸伦物である。

2. 硫酸化脂肪アルニール (R-O- $\left.\mathrm{SO}_{3}\right)-\mathrm{Me}^{+}, \quad(\mathrm{R}-$ $\left.\mathrm{SO}_{3}\right)-\mathrm{Me}^{+}$硫酸化脂肪アルコールとは脂肪アルコール を硫酸て處理して, 親水群 $-\mathrm{SO}_{3} \mathrm{E}$ を導入したものであ る。たよ゙しこれを噼密にいふと，真の硫酸化物は $\mathrm{R}-\mathrm{SO}_{3}$ $\mathrm{Na}$ であつて， R-O- $\mathrm{SO}_{3} \mathrm{Na}$ は硫酸エステルである。 し かしこの兩者は混用されてるる。郎ち葚正の研酸化物は

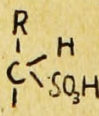

(I)<smiles>Oc1ccccc1</smiles>

(II)
の如く S- 原子が C- 


\section{1}

原子に直結してるなければならぬ。市販の硫酸化物には か〉る構造のものも少數あるが一般に價值が低い。また 脂肪アルュール硫酸エステルから次の樣にらくることも 出來る。

$$
\mathrm{R} \cdot \mathrm{O} \cdot \mathrm{SO}_{3} \mathrm{Na}+\mathrm{Na} \mathrm{SO}_{3}=\mathrm{R} \cdot \mathrm{SO}_{3} \mathrm{Na}+\mathrm{Na} \mathrm{SO}_{4}
$$<smiles>[2H]C(C)(Cl)OOS(=O)(=O)O</smiles>

型のものであつて，これはアルコールの硫酸エステルで ある。これは S- 原子が O-原子を經て C に結合して るる。また市販には $\mathrm{OH}$ 又は $\mathrm{O}-\mathrm{SO}_{3} \mathrm{H}$ と同時にCに直結 の $\mathrm{SO}_{3} \mathrm{H}$ 群を有するるのもある。

郎ち (IV) $R$

$$
\begin{aligned}
& \stackrel{d}{\mathrm{C}}<\mathrm{OH} \\
& \mathbf{d}<\mathrm{H} \\
& \mathrm{C}<\mathrm{SO}_{3} \mathrm{H}
\end{aligned}
$$

(V)

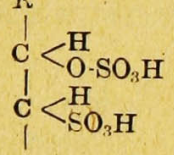

(例，イントラゾル)

以上の型の市販品中代表的なるのはガーヂノル型のもの であつて

$$
\begin{aligned}
& \text { ガーヂノル A } \mathrm{C}_{18} \mathrm{H}_{37} \mathrm{OSO}_{2} \mathrm{Na} \text { オクタデシルア } \\
& \text { ルコール硫酸エステルの罯 } \\
& \text { ガーヂノル CA } \mathrm{C}_{17} \mathrm{H}_{33} \mathrm{OSO}_{3} \mathrm{Na}_{\mathbf{a}} \text { オレイルアルコ } \\
& \text { 一ル硫酸エスデルの綮 } \\
& \text { ガーヂノルWA } \mathrm{C}_{12} \mathrm{H}_{25} \mathrm{OSO}_{3} \mathrm{Na} \quad \text { ラウリールアル } \\
& \text { コール硫酸エステルの暨 }
\end{aligned}
$$

その他りサポル，チクラノン，サンドポン等あり，に れ等は石灰，酸に安定げが强酸には徐々に加水分解する 清淨，精練爲である。

3. 變性脂肪殘基を有する石畧 ( 叉は脂肪酸縮合化合 物) $\left(\mathrm{R}-\mathrm{X}-\mathrm{R}_{1}-\mathrm{SO}_{3}\right)-\mathrm{Me}^{+}$上述のや5に普通石践は $\mathrm{CO}$ $\mathrm{OH}$ 群があるために石灰、酸に不安定である。この缺點 をなくするためには COOOH 群を除き親水群を導入する ことである。その一つの方法は前述硫酸化脂肪アルコー 几の製造には之を接觸還元して $-\mathrm{COOH}$ を $-\mathrm{CH}_{2} \mathrm{OH}$ に する。 $\mathrm{COOH}$ 群の不活性化 (封鎖) の方沠としてその他 にはエステル化法とアミド化法とがある。

エステル化法

$$
\mathrm{R}-\mathrm{C}<\mathrm{OH}_{\mathrm{OH}}^{\mathrm{O}}+\mathrm{R}_{1} \mathrm{OH} \rightarrow \mathrm{R}_{1}-\mathrm{C}<\mathrm{O}_{-} \mathrm{R}_{1}+\mathrm{H}_{2} \mathrm{O}
$$

アミド化法

$$
\mathrm{R}-\mathrm{C}<\mathrm{OH}_{\mathrm{OH}}^{\mathrm{O}}+\mathrm{NH}_{3} \rightarrow \mathrm{R}-\mathrm{C}<\mathrm{NH}_{2}+\mathrm{H}_{2} \mathrm{O}
$$

エステル化によつて安定性を改善すると共に蒸閏能を 示与。但し洗睞能け現はれぬ。アジイロル AHCX (Bōhme) はか」る製品である。但しエステルであるか
ら未だその安定度には限りがある。アミド化はこの㸃エ ステル化より遥かに有效である。これを硫酸化すると一 $\mathrm{O}$ - $\mathrm{SO}_{3} \mathrm{H}$ 群が入り水溶性となる。浸潤琴透劑であるが 清凈力を持たぬ。フメクトルは CX (I. G.)はかつる製

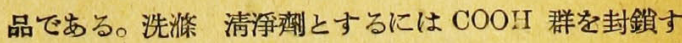
ると共に元來水溶性で石灰斥ひ酸に安定なるアルキル， アラルキル，アリル基を脂肪残基に結合することが必要 である。脂肪酸縮合化合物はかつる製品であつてこれ等 は少數の例外を除き，真正の硫酸化合物たる陰イオン活 性の盬である。縮合する低分子の炭化水素殘基 $\left(\mathrm{R}_{1}\right)$ が 脂肪族か芳香族かによつて製品は脂肪族研酸化合物また は芳香族硫酸化合物の性質を示す。か子る市販品は多數 あるが主要なるはイら゙ポン類, ネオポル類, ウルトラフ オン類、メリオラン，ラメポン等である。

a. イゲポン A (I. G.) これは油酸とオキシエタン スルフオン酸の縮合物である。郎ち

$$
\begin{aligned}
& \mathrm{CH}_{3}\left(\mathrm{CH}_{2}\right)_{7} \cdot \mathrm{CH}: \mathrm{CH}\left(\mathrm{CH}_{2}\right)_{7} \cdot \mathrm{C}<{ }_{\mathrm{OH}}^{\mathrm{O}} \text { (叉はCl) } \\
& +\mathrm{HOCH}_{2} \mathrm{CH}_{2} \mathrm{SO}_{3} \mathrm{Na} \rightarrow \mathrm{CH}_{3} \mathrm{CH}_{2,7} \cdot \mathrm{CH}: \mathrm{CH} \text {. } \\
& \left(\mathrm{CH}_{2}\right)_{7} \cdot \mathrm{C}=\underset{\mathrm{O}}{\mathrm{O}} \cdot \mathrm{CH}_{2} \mathrm{SO}_{3} \mathrm{Na}(x / 2 \mathrm{H})+\mathrm{H}_{2} \mathrm{O} \text { (文は } \mathrm{NaCl} \text { ) }
\end{aligned}
$$

これは一種のエステルであるから石灰及ひ酸に對する 安定度に限度があり特に加熱によつて践化する。羊毛, 人絹の精練力はすばらしく他の洗涂，精練䈟にささる。

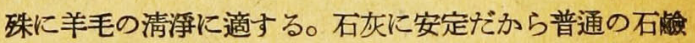
と併用するときカルシウム石龢の沈激に對し保護作用が ある。イゲポン $\mathrm{AP}$ ex は $\mathrm{Na}_{2} \mathrm{SO}_{4}, \mathrm{NaCl}$ 等を含有し $\mathrm{A}$ の表面活性力を改善する。

b. イゲポン T (I. G.) 油酸と N-メチルアミノエ タンスルフオン酸の縮合物である。

$$
\begin{aligned}
\mathrm{CH}_{3}\left(\mathrm{CH}_{2}\right)_{7} \mathrm{CH}=\mathrm{CH}\left(\mathrm{CH}_{2}\right)_{7} \mathrm{C} \gtrless_{\mathrm{Cl}}^{\mathrm{O}} \\
+\underset{\mathrm{CH}_{3}}{\mathrm{HN}-\mathrm{CH}_{2} \mathrm{CH}_{2} \mathrm{SO}_{3}+\mathrm{NaOH}}
\end{aligned}
$$$$
\rightarrow \mathrm{CH}_{3}\left(\mathrm{CH}_{2}\right)_{7} \mathrm{CH}=\mathrm{CH}\left(\mathrm{CH}_{2}\right)_{7} \mathrm{C}=\underset{\mathrm{N}-\mathrm{CH}_{2} \mathrm{CH}_{2} \mathrm{SO}_{2} \mathrm{Na}}{\mathrm{O}}
$$

$+\mathrm{NaCl}+\mathrm{H}_{2} \mathrm{O}$

オレイルメチルアミノェチルスルフオン酸(イゲボン T) これは酸了ミドの誘導體 であつて脂肪殘基と短い

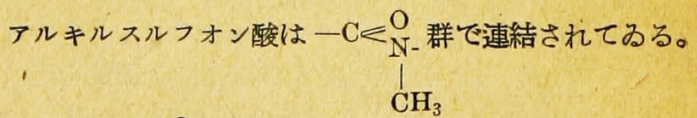
これはーC $\gtrless_{\mathrm{O}}^{0}$ 群より遥かに安定であつて加熱により， 强酸, 强アルカリによつても分解されない。他のいゔれ の陰イオン活性物にるささてるる。故にイゲポン $\mathrm{T} の$ 


\section{用途は頗る廣い。}

c. ネオポル T (ストックハウゼン) 構成はイゲボン T に近似す。故に羊毛の垌淨力良好であると共にカルシ ウム石䖒の分散が大である。

d. メリオラン $\mathrm{F}_{6} \dot{(}$ (オラニエンプルグ) その構造の詳 細は不明であるが恐らく高級なケトスルフオン酸を有す る混合製品と思はれる。脂肪酸監化物と芳香族の炭化水 素，例へばペンゾールを適當な條件の下に縮合し高級な 苊香族ケトン(フェノン類例へばパルミトフエノン)を 作り，これを硫酸化して可活性ならしめる。郎ち

$\mathrm{R}-\mathrm{COCl}+\mathrm{C} \mathrm{H}_{6} \rightarrow \mathrm{RCOC} \mathrm{H} \mathrm{H}_{5} \rightarrow \mathrm{RCOC}_{6} \mathrm{H}_{4} \mathrm{SO}_{3} \mathrm{H}$ 先端に $\mathrm{SO}_{3} \mathrm{H}$ 群を有する買正の芳香族スルフォンたる 陰イオン活性の洗滌椡である。羊毛に對する精練性を示 ナと共にカルシウム石鹸に對する分散劑である。

・e. ウルトラフオン (Ciba) 高級な酸の $\mathrm{COOH}$ 群を 不活性化する別の方法として脂肪酸にヂアミンを作用せ

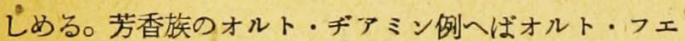
ニレンヂアミンと脂肪酸を縮合せしめると，いはゆるべ ンチミダゾル類を得る。例へば

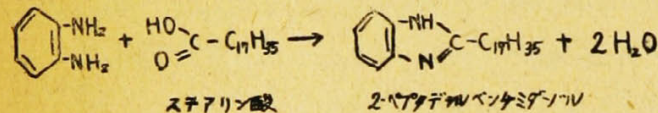

これによつて OH 群が消失すると同時に $\mathrm{COOH} の$ $\mathrm{CO}$ 群も消失し, その C- 原子はへテロ環の構成分とな る。から゙るものを硫酸化すると，ベンゾール核中に 1 個 及は 2 個の $\mathrm{SO}_{3} \mathrm{H}$ 群を導入し, これによつて陰イオン 活性の真正のスルフォン酸ができる。ウルトラフォン類 はか小る製品である。 Kはモノスルフォン酸で, 酸も安 定であり、洗淉劑としてもカルシウム石䶨特に加熱時に おける分散門である。W はヂスルフォン酸で,酸に安定 であり，羊毛に對する精練㻭である。

f. ラメボン $\mathbf{A}$ (グルュナウ) これは脂肪酸の縮合物 として例外的のものて，脂肪酸墭化物と分解蛋白質作用 によつて得られる。

$\mathrm{C}_{17} \mathrm{H}_{33} \mathrm{COCl}+\mathrm{NH}_{2} \mathrm{R}_{1}\left(\mathrm{CONHR}_{2}\right) \times \mathrm{COONa}+\mathrm{NaOH}$ $\rightarrow \mathrm{C}_{17} \mathrm{H}_{33} \mathrm{CONHR}_{1}\left(\mathrm{CONHR}_{2}\right) \times \mathrm{COONa}+\mathrm{NaCl}+\mathrm{H}_{2} \mathrm{O}$ これは脂肪酸と蛋白啠の兩性を有し，先端の SO.H 群

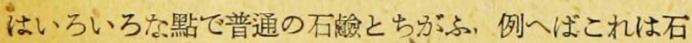
灰に安定であるのみならず，非常に有用なカルシウム石 䶨分散齊である。この際典型的な蛋白質の保護能圥現は す。これに反し酸にはある限度內で安定であり，鑛酸で

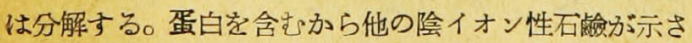
ぬ性質をるつ。羊毛處理の場合に羊毛の蛋白に類似する から，ある程度の保護能を示す。すなはち羊毛のアルカ
リの作用に反作用する。またこれは過酸化水素の安定齊 となる。洗滌能は既述の合成洗滌懠程でない

4. その他の脂肪アルニール鑛酸エステル

a. 燐酸エステル ( $\left.\mathrm{R}-\mathrm{O}-\mathrm{PO}_{3}\right)-\mathrm{Me}^{+}$純粹の燐酸エス テルはない多゙，燐酸と硫酸を同時に又は前後して作用せ しめた混合エステルがある。

b. ピロ粼酸エステル $\left[\begin{array}{l}\mathrm{R}-\mathrm{O} \\ \mathrm{R}-\mathrm{O}\end{array}>\mathrm{P}_{-} \mathrm{O}_{7}\right]^{--} 2 \mathrm{Me}^{+}$脂肪ア ルコールのピロ燐酸エステルは良好な濕潤, 洗㰾能ある 他に過矹曹，過酸化水䓠等の酸化劑の安定作用をもつ。 故に漂白浴で安定劑，濕潤劑として用ひられる。例へば ホモゲニット B, W (Bôhme) 等がある。

c. 過硫酸エステル R-O-SO-O-O- $\mathrm{SO}_{2}-\mathrm{OH}$ 洗滌能 漂白能をるつが市販品の基礎を゙與へてはるかは疑問であ る。

B. 陽イオン活性化合物

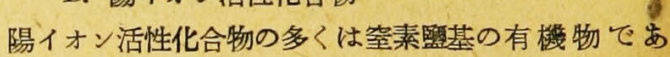
る。すなはち炭素に次いで窒素が重要な元素である。窒 素は 3 價と 5 價と兩方にはたらき， 3 價の場合は $\mathrm{NH}_{3}$ の 型式， 5 價の場合は水酸化又はハロゲン化アンモ=アの 型式の化合物をつくる。そしてその H- 原子を適當な有 機性群て置換すると，空素覺基がでさる。これが1次， 2 次, 3 次の炭化水素系のアミンであり, 叉ビリヂンの 樣な環狀の空素化合物でありまた第 4 次アンモニウム 化合物である。

以上の陽イオン活性化合物と既述の陰イオン活性化合 物を混合すると

$$
\begin{aligned}
& \mathrm{RCOONa} \rightarrow \mathrm{RCOO}-+\mathrm{Na}^{+} \\
& \mathrm{RN} \cdot \mathrm{HCl} \rightarrow \mathrm{Cl}^{-} \stackrel{+}{+} \mathrm{RN} \cdot \mathrm{H}^{+}
\end{aligned}
$$

上の樣な型式で水に不溶性の大きな脂肪分子究作り沈 澱する。この樣に兩者は反對の性質のものであり，陽イ オン活性化合物はアルカリに不安定て酸に安定である。 故に逆行鹸 (inverted soap) 又は酸性石羷 (acid soap) といはれる。酸に安定であるばかりでなく，硬水，重金 螿に安定である。

次に上上の化合物について詳細に䛃明しよ5。 Ro?

1. $\mathrm{NH}_{3}$ 型の 只 $\mathrm{R}-\mathrm{N}-\mathrm{R}_{i}, \mathrm{HAc}$

a. アシル化窒素化合物 RO-NH-R 加」るbのは水 に不溶性だが酸性水溶液中で可溶性コロイドをつくる。 硬水に安定でアルカリで沈澱する。

b. アルキル化ピリヂン化合物

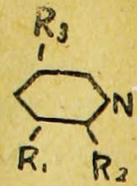


特質は a と同様である。以上 $\mathrm{a}^{\prime}$ 更び b は鍰酸例いば

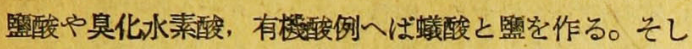
てその型式は $\mathrm{R} \cdot \mathrm{CO} \cdot \mathrm{NR}_{1} \mathrm{R}_{2} \cdot \mathrm{HAc}$ である。賽際の例と してはトリェタノールアミン及びトリエタノールアミン 石踰が离る。トリエタノールアミン $\mathrm{N}\left(\mathrm{C}_{2} \mathrm{H}_{4} \mathrm{OH}\right)_{2}$ （は粘 稒な液體で, アンモニア臭を有し，水に溶解しアルカリ

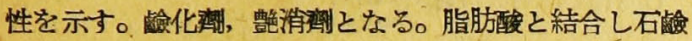
類似物をつくる。 $\mathrm{R} \cdot \mathrm{C} \cdot \mathrm{OH}_{\mathrm{OH}}^{\mathrm{O}}+\mathrm{N}\left(\mathrm{C}_{2} \mathrm{H}_{4} \mathrm{OH}\right)_{3} \rightarrow \mathrm{R} \cdot \mathrm{C}=\mathrm{OH}-\mathrm{HN}\left(\mathrm{C}_{2} \mathrm{H}_{4} \mathrm{OH}\right)_{3}$

その水溶液は中性で PH の價 8.0 であり，清淨劑，乳 化劑となる。トリエタノールアミン類似物に $\left(\mathrm{CH}_{3}\right)_{3} \mathrm{~N} / \mathrm{Cl} / \mathrm{Cl}_{12} \mathrm{H}_{25}$ (ドデシルトリメチルアミン監化物 $)$ がある。監化ドデシルとトリメチルアミンとを作用せし めてつくり，分散劑，均染劑となる。 なたシクロへキシ ルヂェタノールアミンも同樣の性質を有する。
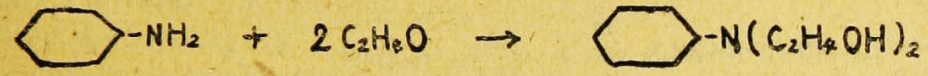

2. $\mathrm{NH}_{4} \mathrm{OH}, \mathrm{NH}_{4} \mathrm{Cl}$ 型のbの，第 4 次アンモニウム 化合物，ビリヂン籃類

$\mathrm{NH}_{3}$ の荎素は容易に 5 價に變はる。すなはち

$\mathrm{NH}_{3}+\mathrm{H}_{2} \mathrm{O}=\mathrm{NH}_{4} \mathrm{OH}$, 同樣 $\mathrm{N}\left(\mathrm{C}_{2} \mathrm{H}_{4} \mathrm{OH}\right)_{3}+\mathrm{H}_{2} \mathrm{O}$ $=\mathrm{N}\left(\mathrm{C}_{2} \mathrm{H}_{4} \mathrm{OH}\right)_{3} \mathrm{OH}$

同样にピリヂンのNもまた容易に 5 價に變はる。すな はち

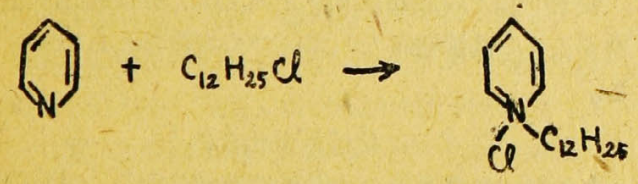

か」る 5 價の窒素を有する化合物は助倣として新しい 領域をひらいた。これ等を第 4 次アンモニウム化合物と いひ，ピリデン化合物の例が多い。そしててれ等はピッ ヂンKハロゲン化物を作用せしめて得られる。例へぱ

\section{$\left.\mathrm{C}_{16} \mathrm{H}_{28} \mathrm{BT}+\mathrm{O} \rightarrow\left(\mathrm{C}_{16} \mathrm{H}_{23} \cdot \mathrm{H} \cdot \mathrm{C}_{\mathrm{C}} \mathrm{H}_{5}\right)^{4} \mathrm{Cl}^{-}\right]$}

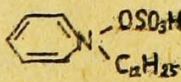

同様にオクタデシルクロロメチルエーテル $\left(\mathrm{C}_{18} \mathrm{H}_{37} \cdot 0 \cdot \mathrm{CH}_{2} \mathrm{Cl}\right)$ にビリヂシを作用せしめて ラウリはと゚゚ナ゙ーウム 硫酸垠。

Velan 型防水劑たるオクタデシルオキシメチルピリヂ= ウム監化物方得られる。これ等の第 4 次アンモニウム化 合物の用途は甚デ庴い。次にこれを列學すれば，
1. 拔染。アンスラキノイド，インデゴイド，ハイド ロンブルー型建染染料は第 4 次アンモニウム化合物 を含さ還元齌のアルカリ溶液で拢染される。

2. 堅暒度堙進。長い陽イオン鎖は長い陰イオン鎖と 作用し，不溶性化合物起作るから水洗に對する堅牢 度を堙進する。

3. 均染。脂肪ビリヂニウム化合物は建染染料への强 い抑制力があるから均染せしめる。すなはち陽イオ ン鎖が染料と結合し次に徐々に分解して染料を瀻維 へ移動せしめる。故に初め陽イオン化合物起入れて 染色し, 吸盡に近くなつ代頃に陰イオン化合物を加 へて染色を進める。

4. ラテックスの漻透。ラテックスを瀻維に與へるこ とは, 從來不可能であつたが，陽イオン活性化合物 によつて可能とない\%。すなはち閦質ゴムは負電荷 を有するから，繊維を先つ陽イオン化合物で處理し

で特いて正電荷を與へて呿き，

次に 10〜15\% のラテックス夜 を通すとゴムが吸收されて繊維 を㠅包する。

5. 仕上。繊維素瀻維は水中で負の電荷を有する。故 に陽イオン活性化合物を吸收するから，これで仕上

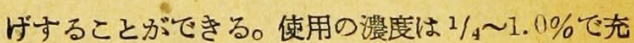
分である。

6. 媒染及び固着。整基性染料を例外とし他の染料は すぺて負電荷のイオンを作るから陽イオン化合物と 結合する。故に媒染，固着に役立つ。

7. 防染。第 4 次アンモニウム監，燐正び第 3 次硫黄 化合物で押染すると，建染染料還元體の防染劑とな る。

8. 人絹の翼消。人絹の鄷消濟, 例へば $\mathrm{ZnO}, \mathrm{TiO}$, Ba- 監等は陽イォン化合物の存在で正電荷を 有する粒子を作りこれが繊維に附着して噃 消する。

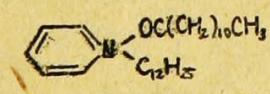

ラウクリと゚リダニクム

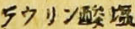

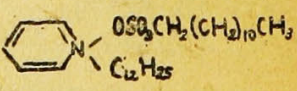

テロリルピクダニウム

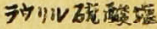

これ等はリべラトの名で市販せられる人絹鄷消濟で ある。

9. 防水。オクダデシルクロロメチルエーテルはピリ 
ヂンと縮合して，ビリデニウム監化物を作り水溶性 となる。これを加熱すると分解して，ピリデンを放 出しクロロメチルエーテルク繊維と化合し，新なる 防水性の纎維誘導體を作る。以上のピリヂン化合物 が防水劑ヴエラン PF (英國 I.C.I. 社) であり，そ

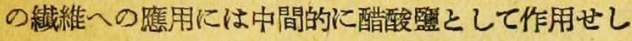
める。すなはち

(a) 纎維素の防水
る。酸性より中性て安定，石灰に安定であるがアルカリ

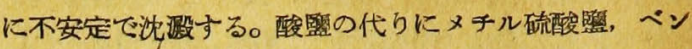
ヂル監化物でアルキル化するとアルカリに安定になる。

$\mathrm{C}_{27} \mathrm{H}_{33} \mathrm{CONHC}_{2} \mathrm{H}_{4} \mathrm{~N}\left(\mathrm{C}_{2} \mathrm{H}_{5}\right)_{2} \cdot \mathrm{CH}_{3} \mathrm{COOH}$ サパミンA 醋酸蹪)

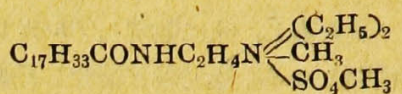

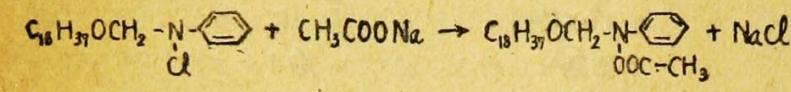
$\mathrm{C}_{18} \mathrm{H}_{3} \mathrm{OCH}_{2}-\mathrm{N}-\mathrm{HOCH}_{2}-\mathrm{CH}^{-\mathrm{CH}} \mathrm{CHOH}$ $\mathrm{OOC} \cdot \mathrm{CH}_{3}$

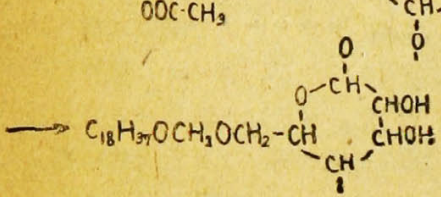

(b) 羊毛の場合

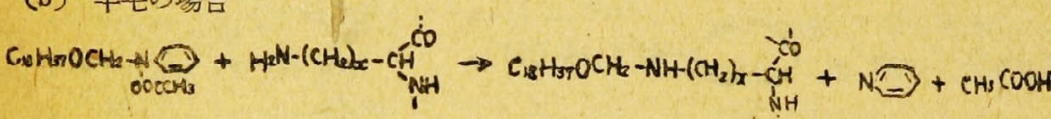

類似の防水濟方酸了ミド<smiles>[R]OC(=O)NCc1ccccc1</smiles>

脂肪カーバミンエス

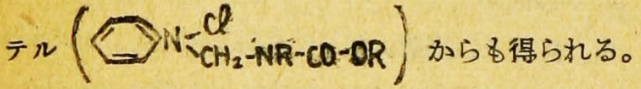

10. 柔軟。陽イオンは炭化水素の長鎖をそのを入又は その他のるのと結合の形で含有し繊維に絹絲狀の柔 軟性を與へる。

附 陽イオン活性化合物の滿淨，洗滌力は小さい。何 故ならば瀻維は液中で負電荷をとる。瀻維上の污物 は陽イオン化合物の濕潤力のために或量は直ちに剥 落する。然し液中の污物の粒子は陽イオン化合物を

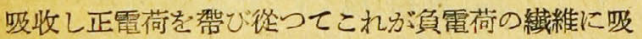
收され䄉維上に沈澱するからである。

第 4次アンモニウム化合物 (陽イオン活性化合物)の 代表的な市販品はサパミン類 (Ciba) であり固着劑，均

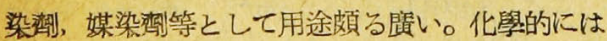

$\mathrm{C}_{7} \mathrm{H}_{33} \mathrm{CO} \cdot \mathrm{NH} \cdot \mathrm{CH}_{2} \mathrm{CH}_{2} \mathrm{~N}<\mathrm{C}_{2} \mathrm{C}_{5} \mathrm{H}_{5}$ の監である。

$\mathrm{COOH}$ が封鎮されてをり不活性になつた石䃋と去ふ よりるむしろ酸アミドである。ヂエチルエチレンヂアミ ンと油酸を加第して作りデエチルアミノエチルオレイル アミドである。無機，有機の簡單な酸と結合して監を作 用ひられるのである。

- サパミン MS (メソ硫酸霊)

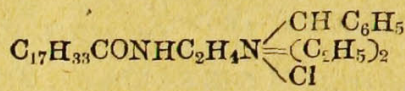

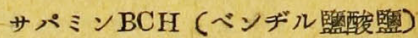

第 4 次アンモニウム化合物の類似物として燐，硫黄化 合物が同一の目的に用ひられる。水素と硫黃叔よび哠の

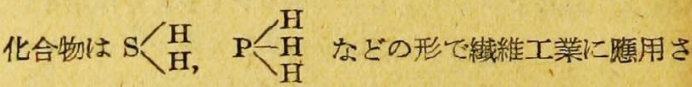
れるのでなくその水素を有機群で置換し更にハロゲンア ルキルで虎理すると硫黃 が4價，Pが5價の化合 物を作り之ぶ助齌として

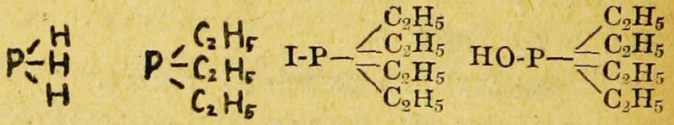

$$
\begin{aligned}
& \text { テトラエチル テトラエチル } \\
& \text { フオスフイン フォスフイン } \\
& \text { 沃化物水酸化物 }
\end{aligned}
$$

炭素 6 以上の脂肪族炭化水素又は芳查族炭化水素群安 有するるのは唀劑として铁うて均染劑として用いられ る。

\section{C. 非イォン化性活性化合物}

この種の助衤はその水溶性は造監群たる -COONa, $\mathrm{O} \cdot \mathrm{SO} \mathrm{Na}$ 文は $\mathrm{SO}_{3} \mathrm{Na}$ によるすのでなく $\mathrm{OH}$ 群による ものである。酸化エチレンと高䌅アルコール，アルキル アミド、アルキル類アミドを縮合して得られる。その構 戚ふら 2 種に分ける。一つは㞸化水素力゙天然に存するす の，他は合成的なものである。

× 天然脂肪加らなるすの

これに屬する製品にはぺレガルＯ(I. G.)，レオニル O (I. G.) 等汃活る。

a. ペレガル O (I. G.) オクタデシルアルニール に 15〜20モルの酸化エチレンを縮合して作る。

$\mathrm{C}_{88} \mathrm{H}_{7} \mathrm{OH}+(15 \sim 20) \mathrm{C}_{2} \mathrm{H}_{4} \mathrm{O} \rightarrow \mathrm{C}_{18} \mathrm{H}_{38} \mathrm{O}$.

$\left(\mathrm{C}_{2} \mathrm{H}_{4} \mathrm{O}\right)_{11-19} \mathrm{C}_{2} \mathrm{H}_{4} \mathrm{OH}$

本品は白色固形で水に溶解し溶液狀で販賣される。濕 
潤, 起泡, 洗桬の,能力があるがしかしイォン化性のるの におよばぬ。均染㵯として適當である。又その清淨作用

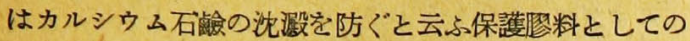
すぐれた作用に裹付けされてるる。この點てはむしろ最 良の陰イオン性石数にまさる。

b. レオニルO (I.G.) 本品の正確な構造はまだ轩 つて居ない。そ声淨力は浴の $\mathrm{PH}$, 纎維と液の間の電 荷に無關係である。白色の固體で水に透明に溶解し，溶 液のま〉市販される。

B. 合成脂肪族からなるもの

この種のものでは全く合成的なるのである。その一般 式は $\mathrm{R}-\mathrm{O}-\left(\mathrm{C}_{2} \mathrm{H}_{4} \mathrm{O}\right) \mathrm{nC}_{2} \mathrm{H}_{5} \mathrm{OH}$ でこの R は招そらく分枝 を有する合成の炭化水素類であらう。その長さは知られ て居らぬ方湠素數が 12 から 6 のるの, 酸化エチレンの 數は 5〜10個である。この種のものでは陰イオン石呤と は根本的に異る。電離する群も造祭群もないから水に分 散した場合は中性て酸了ルカリ，金屬監等に完全に安定 である。どのPA に括いても洗淉力有するが中性か

\section{[29 頁より]}

\section{本邦火藥工業の近況}

種類 火菜には黑色火䔀と無烟火菜とあり，爆發には ニトログリセリン゙゙主懠とする膠質ダイナマイトと硝安

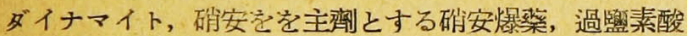
アンモニアを主劑とするカーリットの 3 種がある。文火 工品は工業雷管, 電氣雷管, 導火線とに分れている。

製造工場 終戰までは陸軍の宇治と岩鼻とで産業用爆 菜空製造していたが，民間工場の昭和火藥與津工場（カ ーリット生產) と共に賠償指定となつた。現在爆菜は, 日本化菜厚狹, 旭化成延岡, 日産化學武豊, 關束電氣工 業保土谷 (カーリット生產)で製造している。黑色火架 は，日本化栾の工場戰秌のため岩鼻の賠償施設の一部を 借りて製造されている。工業雷管は日本化藥2工場, 旭化 成 1 工場 (東京工場は製造停止，需要增加すれば再開の 可能性がある), 帝國火工品 1 工場, 電氣雷管は日本化菜 2 工場, 旭化成 1 工場, 帝國化工品 1 工場の外, 唐津, 九州火工品各 1 工場分あるる導火線は日本化桑 2 工場の 外は, 旭化成, 關東電氣工業, 帝國火工品, 關東導火線, 三田商店各 1 工場ぶある。北海道础川の硝安爆菜工場再 開摡請中なるも爆㩰の供給力は充分であるとの理由でま て許可がない。

爆藥生產量 戰前は昭和 5 年 $10,693 \mathrm{t}$ より逐次堵加 して同 12 年には $27,828 \mathrm{t}$ を示し, 戰時中は更に增加
弱アルカリ性で最良である。加熱すると幾分分解し液は 少し溷濁する。そして冷却すると透明になる。洗淉力は 加熱にあつて少しも影響されねるか人るもので最良の市 販品はイゲパル $\mathrm{C} ， \mathrm{~W} ， \mathrm{~L} ， \mathrm{~F}$ 括よびレオニル WS (何 れも I.G) である。

(2) 合, 成 樹 脂

繊維工業に抠ける最近の撜達の興味ある一つである。 今日合成樹脂ととないられるものに石炭酸樹脂, 尿素樹 脂，グリプタル樹脂，ヴイニイル樹脂等がありこれ等は 繊維の加工には防卿，硬仕上，擬麻加工等の方面に應用 されてるる。

\section{(3) 繊維素誘導䁗}

纎維素誘導體として從來繊維素の銅アンモニア液，ヴ イスコーズ，ニトロ繊維素が用ひられてるたが最近その 他の繊維素エーテル等が用ひられてるる。これ等のすの は主として接合劑，糊料，仕上劑之の他前記合成樹脂と 共通の方面に利用されてるる。

\section{(學振第 12 小委員會委員)}

して同 15 年には $31,055 \mathrm{t}$ の最高實績を示した。その 後次第に低下して, 同 19 年には $24,613 \mathrm{t}$ に下゙り, 20 年には終戰のため僅に $5,537 \mathrm{t}$ ，とい5最低生產量に低 下したぶ，產業の基盤として石炭の增產が至上命令とな つたのに應じ，爆燥の需要も睤加し，21 年 $9,017 \mathrm{t}, 22$ 年 $11,490 \mathrm{t}$ と生座艺恢復し, 23 年度計畫は $17,500 \mathrm{t}$ に 又復興計畫では 24 年度 $20,000 \mathrm{t}$ から，28 年度 28 , 500 七 となつている。

石炭 $1 \mathrm{t}$ 採掘に要する爆桇量 炭鐄の採㻕が淮さにつ れ，條件が腎くなるたる，昭和 16 年 $210 \mathrm{~g} ， 18$ 年 225 $\mathrm{g}, 20$ 年 $248 \mathrm{~g}, 22$ 年 $268 \mathrm{~g}, 23$ 年は $280 \mathrm{~g}$ となり, 經 濟復興計畫では 28 年 $310 \mathrm{~g}$ 少㸧定されている。

產業爆藥の製造訴可 終戰後 $\mathrm{GHQ}$ で，爆藥製造䕀 止の意向があつたが，爆藥の性質上，遠く外國からの輸 送上の危险，長期䠉藏による爆萎効力の減退，氣候の影 響を受ける等の理由て，國內製造許可の申声が容れられ， 必要量だけは製造出來ることとなつた次第である。

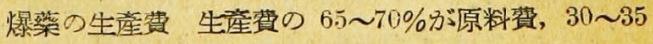
\%が人件費となつている。原料としては，グリセリン， パラフィン，紙等ア゙不足資材であり，硝酸，硫酸，アン モニア等は, 化學肥料の生產と競合寸るために, 原料費 が高くついている。

(日化協月報，第 4 號，昭和 23 年 9 月) (北脇) 